\title{
Teaching Reform of Foreign Trade Document Business Course Based on POCIB Internet Practice Platform*
}

\author{
Lihong Zhao \\ Jilin Engineering Normal University \\ Changchun, China 130031
}

\begin{abstract}
The foreign trade document is an operating skills curriculum that involves a wide range of fields and is practical, based on theory, and characterized by practice. First introduced the POCIB practice platform, then according to the characteristics of the international trade document curriculum, analyzed the problems in the traditional teaching of international trade document curriculum. Finally, the suggestion that the international trade document course needs to be combined with the POCIB platform for teaching is proposed.
\end{abstract}

\section{Keywords-POCIB; document; international trade}

\section{INTRODUCTION}

Documentary business is an important part of international trade. From the signing of trade contracts to the fulfillment of contracts, every link is inseparable from documents. Therefore, students of international trade major need to grasp various kinds of documents involved in all aspects of import and export business process. Document production requires format specification, specific requirements and operation methods such as the analysis of the terms of the contract, the audit of the letter of credit, the production of documents, the audit of documents, the filing of documents, and the ability to correctly make the foreign trade documents and deal with the business problems of the documents. The changes in foreign trade have put forward higher requirements for the practical teaching of foreign trade documents. The practice teaching of foreign trade documents in the universities must highlight the training of the "post ability" of the students, and reform the practice teaching model of foreign trade documents according to this goal [1].

\section{POCIB INTERSHIP PLATFORM}

POCIB (Practice for Operational Competence in International Business) is a comprehensive training platform for international trade majors. It is the Internet training certificate course jointly launched by the international trade journal and the software company after the China International Trade Association (China International Trade

*The Project: Teaching reform of foreign trade document business course based on POCIB Internet practice platform, 2016
Association), following the test projects of the foreign salesman and the merchandiser, and so on. The POCIB project focuses on the students of international trade and related majors and the new people in the international trade industry, aiming at improving the foreign trade skills of the learners, and taking the Simulation online international trade game as the core method, and introducing an innovative, efficient, pragmatic and scientific teaching method for the training of foreign trade talents in our country. POCIB is held two times a year, each time is twenty days. During this short period, the students of international trade in Colleges and universities completed twenty different trades, including import and export documents, through the platform. The knowledge and skills produced by these documents reflect the teaching contents and requirements of the foreign trade documents business course.

\section{THE CHARACTERISTICS OF THE COURSE OF FOREIGN TRADE DOUMENTS}

The Business of Foreign Trade Documents is an important core course for international economic and trade majors. It is a practical and practical course of business skills. It is a core professional skill course which combines the professional knowledge of international trade with professional English. Therefore, the course "Business of Foreign Trade Documents" also has strong foreign related characteristics. The theory and practice of this course are combined to introduce the types, uses, and applications of the import and export documents, and the application in the foreign trade practice. Through specific theoretical narration, multimedia demonstration, case teaching and other teaching methods, students are required to master the types, functions, contents, methods of renovation, auditing skills and the production of documents. The basic theory and key points should be mastered in the process, the procedure of circulation of foreign trade documents, the operation and management of foreign trade documents, and the ability to master the documents. The characteristics of the course "foreign trade document business" require students of international trade to enter the study after finishing other related professional courses. Therefore, students should master the following requirements. 


\section{A. Foreign Language Ability}

As the business of foreign trade documents is very foreign related, students are required to have a strong command of foreign languages, especially business English. The course of foreign trade document not only requires students to read in English, but also requires the students to make up the documents in English, especially in the enterprise foreign trade merchandisers, which also require communication with the customers, and this kind of communication is usually carried out in the way of oral English and business correspondence. Therefore, the course of foreign trade document business not only emphasizes the students' mastery of the ability of English making, but also requires the application of business oral ability and the mastery of writing skills in business correspondence [2].

\section{B. Professional Knowledge}

The characteristics of the course "foreign trade document business" require students of international trade to enter the study after finishing other related professional courses. Therefore, students should master the relevant professional knowledge of international trade. The course of foreign trade document business will focus on the remailing and modification of documents, and the knowledge of international trade theory related to it requires students to learn and master in advance. For example, the term of trade in international trade is explained in the course of international trade practice. It will not be explained in the course of foreign trade document business, but it is directly applied to the signing of the contract.

\section{Participation in Documentary Related Competitions}

After the study of the foreign trade document business, we can take part in the competitions related to the foreign trade documents according to the knowledge and skills they have learned, to promote learning by competition and to promote the practice by competition, and to require international trade majors to have entries. For example, let students participate in the POCIB competition, the national foreign trade documents post skills competition and other competitions. The simulation software platform can provide students with professional skills training platform. Therefore, in order to meet the requirements of the enterprise in the future, the students of international trade major will participate in the related competition to improve their professional skills after the end of the theory teaching [3].

\section{PRoblems In Teaching Methods of Foreign TRADE DOCUMENTS BUSINESS}

In the traditional teaching of foreign trade document business, emphasis is placed on theoretical teaching, and there are some major problems in teaching methods.

\section{A. The Teaching Method Is Not Flexible}

"Foreign trade document business" courses are mostly taught by teachers on the platform, and students take notes as the main teaching methods. Students are rare to master the application and practicality of the business knowledge of foreign trade documents, and the teaching means are not flexible.The course of foreign trade documents involves letters of credit, commercial invoices, packing list, shipping bill of lading, insurance policy, general certificate of origin, certificate of origin of origin, bill of exchange, certificate of beneficiary, shipping notice and so on. These documents run through the whole process of import and export business and have a wide range of contents. Relying on traditional teaching, students can easily confuse the knowledge and skills of documents. However, there are many kinds of documents and complex relations. Teachers have more time to explain the related concepts, and the explanation of the concept is relatively boring, which leads to the students' passive learning and the poor learning effect.

\section{B. The Case Material Is Mainly Static}

It is difficult to mobilize the enthusiasm and initiative of the students. Most of the students are passive in learning knowledge and tasks, and cannot flexibly grasp the requirements and rules of document repair.Teachers in the classroom because of the restrictions on teaching time, after explaining the case, there is no time to carry out classroom training for students. Students only passively remember the teacher's explanation, but they can't take the initiative to master the skills of making orders.

\section{Poor Practicality}

In the teaching process of the foreign trade document business, the static teaching case leads to the students' ability to make the bill and the actual requirements of the enterprise, and the practice is insufficient.The actual documents of the enterprise are numerous and complex. The students are only listening to the teacher's explanation in the classroom. There is no practical operation to combine the skills with the knowledge. And the characteristics of the foreign trade document business is a practical and practical course. The students' poor practice will lead to the students' failure to adapt to the requirements of the foreign trade enterprises after graduation.

\section{TEACHING In COMbination With Pocib PlatForm}

In order to enable students to master the knowledge and skills of foreign trade documents, they can change passive learning into active learning and arouse students' enthusiasm. POCIB practice platform mainly examines students' learning ability, professional ability and merchandising ability. To obtain POCIB certificate, the total score must be 60 points, and the three items of learning ability, business ability and ability to follow up must reach 60 points to qualify for the certificate. In the POCIB merchandising ability, we mainly examine the students' mastery of import and export documents and their application skills.

\section{A. Mobilizing Enthusiasm}

After introducing POCIB into the classroom, students' initiative can be mobilized. Because every student runs a foreign trade company, students have to make budget and fill in the bill if they want to run their own company well. The 
documents must be accurate, timely and complete. In the course of competition, the ability of POCIB's merchandising is to examine the contents of the documents. Thus, students learn from passive learning and take the initiative to add corresponding documents in the trade process and repair them.

\section{B. Expanded the Scope of the Documents}

The POCIB practice platform provides more than 60 kinds of import and export trade documents in the document making business. It is no longer confined to book examples, but also more diversified. It is mainly divided into import and export documents[4].

Export documents include: commercial invoice, packing list, international shipping Commission, international air transport entrustment, application identification form, exit goods inspection form, general origin certificate, GSP certificate of origin, policy sheet, export goods declaration form, collection commission, export deposit application, bill of exchange, and domestic remittance application[5].

The import documents include the application for remittance in China, the application for the irrevocable letter of credit, the application for amendment of the letter of credit, the policy sheet, the application for claim, the declaration form for the entry goods, the customs declaration form for the import goods, the application for the remittance abroad, etc.

Through the improvement of the different documents, the students improved their own production skills, made different documents through different contracts and trade terms, increased the students' understanding of the documents, and improved the skills of making the bill.

\section{Flexibility}

As the practice platform is carried out in the form of the Internet, the international trade transaction is carried out through the simulation software platform. It is required to operate an import and export enterprise in the course time and maximize the profit by playing a full game under the dynamic market environment. In the fifth POCIB competition, there were 276 institutions and 7300 participants. The students who participate in the competition are not only in accordance with the rules of the competition, but also with different demands from different customers, and the combination of different settlement methods and trade terms. Therefore, the type and number of documents and the requirements for document repair are also changed by the different types of trade. Students should also be flexible in making production documents. For example, if the two parties stipulate the T/T settlement in the contract, the importer may not need to apply for a letter of credit in making the documents. Therefore, the practice platform brings flexibility to the production of foreign trade documents[6].

\section{Combination of Theory and Practice}

Although the POCIB platform can provide many advantages for the production of foreign trade documents, these advantages are also what traditional teaching hopes to achieve. However, the simulation software is not perfect. For example, the financing of importers and other issues have not been resolved, and some of the changes in the production of documents need to be improved.

Therefore, in a comprehensive way, POCIB is an auxiliary part of the class teaching of international trade specialized courses. The teachers should arrange the time arrangement of the theoretical knowledge learning part and the practical training part reasonably, and achieve the best teaching effect through the coordination and coordination of the two parts[7].

\section{CONCLUSION}

Under the traditional teaching theory, the "foreign trade document business" is based on the use of simulation software and the network environment, taking the students' actual operation as the core, making the students become the subject of the curriculum, and promoting the students to change their passive learning into active learning. At the same time, the theory and practice are combined to train students to identify various complex documents in the process of practice, to master the ability to fill in various kinds of documents and to accumulate experience in practice, so as to improve the efficiency of the classroom and the ability of students to analyze and solve problems.

\section{REFERENCES}

[1] Y.W.Zheng,Internet plus "vouching" flipped classroom teaching mode and practice,Journal of Lanzhou Institute of Education, 2016,05

[2] D.Q.Chen,Germany's dual System of Vocational Education Revisited,China's Higher Education Research,2016,(2)

[3] Y.Chen,German dual System of Higher Education System,Foreign Educational Research,2015(6)

[4] F.Wang, Practice Teaching Reform of International Trade based on POCIB Project. Explore,Education and Teaching Research.2016(1)

[5] C.F.Liu,POCIB Comprehensive Training Deficiencies and Countermeasures: Higher Education Journal,2016 (20） : 158-189.

[6] Q.Y.Ge and Y.L. Zhao,New Thinking on the Teaching Mde of International Trade under the New Normal Economic Situation,Higher Education Journal, 2016 (1): 54-55+57.

[7] Y.Y.Tian,Precise Statement on International Trade Documents (Fourth Edition) [M]. Beijing: China Customs Publishing House, 2015.1 . 